https://journal.literasisains.id/index.php/ABDIKAN

ISSN xxxx-xxxx (Media Online) | ISSN xxxx-xxxx (Media Cetak)

Vol. 1 No. 1 (Februari 2022) 64-68

DOI: $x \times x x x$

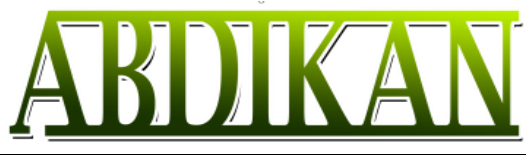

Diterima Redaksi: 13-02-2022 | Selesai Revisi: 17-02-2022 | Diterbitkan Online: 22-02-2022

\title{
Mahasiswa Kesejahteraan Sosial FISIP USU Meningkatkan Minat Baca Anak Panti
}

\author{
Michael Dolok Saribu \\ Program Studi Kesejahteraan Sosial, Fakultas Ilmu Sosial dan Politik, \\ Universitas Sumatera Utara, Medan, Indonesia \\ Email: michaelds031@gmail.com
}

\begin{abstract}
The author did practicum II at the Ora Et Labora Nusantara Orphanage. The second practicum carried out by the author was to examine the problems experienced by orphans. The problems experienced by orphanages are the lack of reading culture so that they have difficulty in learning. Especially during the current pandemic, children prefer to spend time playing with their friends at the orphanage rather than taking the time to study. From this problem, the author is interested and has the aim of increasing interest in reading for orphans which is a mini project from this author on education to children. The author has a client (group) who is experiencing this problem. The group consists of children who are still in elementary school (SD). The author uses the stages of social groupwork in his research from the preparation stage to the termination stage. The method used is the Delphi method using Focus Group Discussion (FGD). After doing all the stages of social groupwork, the results are presented by the author so that the orphanage children can continue the reading culture so that they have no difficulty in learning at school.
\end{abstract}

Keywords: Orphanage, Field Practice II, Interest in Reading, Education.

\begin{abstract}
Abstrak
Penulis melakukan praktikum II di Panti Asuhan Ora Et Labora Nusantara. Praktikum kedua yang dilakukan oleh penulis yaitu meneliti tentang permasalahan yang dialami oleh anak panti. Adapun masalah yang dialami oleh anak panti yaitu kurangnya budaya membaca sehingga mengalami kesulitan dalam pembelajarannya. Apalagi dimasa pandemi sekarang anak lebih suka untuk meluangkan waktu untuk bermain dengan teman-temannya di panti dibanding meluangkan waktu untuk belajar. Dari masalah tersebut maka penulis tertarik dan memiliki tujuan untuk meningkatkan minat baca anak panti yang merupakan mini project dari penulis ini terhadap pendidikan kepada anak. Penulis memiliki klien (kelompok) yang mengalami masalah tersebut. Kelompoknya terdiri dari anak yang masih duduk dibangku Sekolah Dasar (SD) Penulis menggunakan tahapan social groupwork dalam penelitiannya dari tahap persiapan sampai dengan tahap terminasi. Metode yang dilakukan yaitu metode delphi dengan menggunakan Focus Group Discussion (FGD). Setelah melakukan semua tahapan social groupwork adapun hasil yang dihadapkan oleh penulis agar anak panti dapat meneruskan budaya membaca sehingga tidak kesulitan dalam melakuan pembelajaran di sekolah.
\end{abstract}

Kata Kunci: Panti Asuhan, Praktek Kerja Lapangan II, Minat Baca, Pendidikan.

\section{A. PENDAHULUAN}

Kegiatan Praktek Kerja Lapangan kedua dilaksanakan di Panti Asuhan Ora Et Labora Nusantara yang beralamat di Jalan Agenda No. 11 Ayahanda, Medan, dengan mahasiswa praktikan Michael Doloksaribu (Nim 180902037) dan Supervisor Sekolah yaitu Ibu Hairani Siregar, S.Sos, MSP. Kegiatan PKL II ini berlangsung selama kurang lebih 3 bulan yang dimulai dari tanggal 7 September 2021 sampai 3 Desember 2021. Panti asuhan ini sudah menampung sekitar 30 orang, 4 pengurus, serta bapak pendiri panti sekaligus pengasuh yang bernama Bapak Salim. 
Pada awal bulan september 2021, saya melakukan pertemuan pertama dengan mengadakan observasi dan perkenalan diri dengan anak-anak asuh yang ada di dalam panti asuhan ini. Setelah berkenalan dihari berikutnya, saya mengadakan mini games, bernyanyi bersama, menggambar-mewarnai bersama anak panti hal ini ditujukan agar lebih dekat dan mengenal anak panti. Kemudian pada pertemuan selanjutnya saya melakukan kegiatan belajar-mengajar bersama anak-anak supaya anak mendapatkan pengetahuan baru sehingga bisa menjawab soal-soal yang diberikan oleh ibu guru dengan benar.

Dalam pelaksanaan PKL II, Penulis mendapatkan sekelompok anak yang kesulitan dalam belajar dan menjawab soal-soal yang diberikan oleh gurunya di sekolah. Dengan melihat masalah tersebut penulis membuat mini project untuk meningkatkan kemauan membaca dan belajar anak di masa pandemi yang diharapkan bisa berjalan dengan baik. Mini Project dibuat menggunakan tahapan sosial groupwork secara umum. Penulis mempunyai klien berbentuk kelompok dengan berisikan 5 orang yaitu Buala, Febe, Yanu, Roni, Harianto. Mereka masih duduk dibangku Sekolah Dasar (SD).

Tujuan dari Praktek Kerja Lapangan ini adalah untuk meingkatkan minat membaca pada anak Panti Asuhan Ora Et Labora Nusantara. Kelompok yang dibuat akan melaksanakan tahapan-tahapan sosial groupwork secara umum. Dalam proses pemecahan masalah maka penulis memberikan beberapa perencanaan yang menjadi solusi dari permasalahan kurangnya membaca antara lain : kegiatan membaca buku, kegiatan belajar sambil bermain, kegiatan belajar dan membaca dengan media seperti youtube dan kegiatan sharing mengenai pembelajaran disekolahnya.

Kajian teori yang penulis gunakan adalah kajian teori social learning dari Albert Bandura yang mengatakan bahwa orang dapat mempelajari informasi baru dan perilaku dengan melihat orang lain. Jd dalam pelaksanaanya teori ini dipakai sebagai pedoman dalam penyelesaian masalah yaitu dengan program tentang menumbuhkan minat baca pada anak itu sendiri. Adapun hasil yang diharapkan oleh penulis agar anak panti dapat terus menerapkan budaya membaca sehingga tidak kesulitan dalam melakuan pembelajaran di sekolah

\section{B. PELAKSAAN DAN METODE}

Metode penelitian yang digunakan dalam pelaksanaan praktek kerja lapangan di Panti Asuhan Ora Et Labora Nusantara adalah memakai metode kualitatif. Metode penelitian kualitatif adalah penelitian yang bersifat deskriptif yang lebih menggunakan analisis. Proses dan makna lebih ditonjolkan dalam penelitian kualitatif. Landasan teori dimanfaatkan sebgai pemandu agar fokus penelitian sesuai dengan fakta yang terjadi di lapangan (panti). Untuk itu penulis harus berinteraksi secara dekat dengan kelompok anak sebagai klien sekaligus sasaran dari penelitian ini agar bisa mengenal kehidupan anak di panti. Berikut tahapan pelaksanaan mini project :

1. Tahap Persiapan

2. Tahap Assessment

3. Tahap Perencanaan Alternatif Program

4. Tahap Pemformulasian Rencana Aksi

5. Tahap Pelaksanaan Program

6. Tahap Evaluasi dan Hasil Perubahan

7. Tahap Terminasi

1. Tahap Persiapan

Pada tahap ini Michael mempersiapkan pendekatan yang akan dilakukan untuk pengembangan kelompok anak guna memaksimalkan tujuan dari mini project yang dibuat. Kemudian persiapan lapangan saya lakukan untuk melihat kondisi agar mendapat dukungan atau partisipasi anak-anak untuk melakukan perubahan untuk mencapai tujuan. Pada persiapan ini praktikan telah melakukan observasi lapangan pada tanggal 7 September 2021.

\section{Tahap Assessment}

Pada tahap ini saya menggali permasalahan yang dialami oleh kelompok anak panti. Setelah kelompok dibuat saya mengajak anak-anak untuk saling memperkenalkan diri. Nama klien yaitu: Buala, Febe, Yanu, Harianto, dan Roni. Dalam melakukan perkenalan, saya mengajak anak untuk menceritakan masalah yang mereka alami. Menggali masalah menggunakan metode FGD (Focus Group Discussion). Setelah memfokuskan diskusi dalam kelompok saya mendapat masalah yang dialami oleh mereka yaitu kurangnya kemauan membaca sehingga tidak bisa menjawab soal-soal yang diberikan oleh guru mereka di sekolah. 


\section{Tahap Perencanaan Alternatif Program}

Pada tahap ini saya merencanakan sebuah program agar anak lebih gemar membaca. Peran saya dalam mini project sebagai fasilitator dan educator. Teori yang saya gunakan yaitu teori social learning yang mengatakan bahwa orang dapat mempelajari informasi baru dan perilaku dengan melihat orang lain. Dengan merencanakan program maka saya sebagai praktikan bisa menyesuaikan dengan program yang diharapkan untuk menyelesaikan permasalahan mereka sehingga nantinya bisa berjalan sesuai yang diharapkan.

\section{Tahap Pemformulasian Rencana Aksi}

Pada tahap ini pelaku perubahan membantu masing-masing anak untuk merumuskan dan menentukan program mana yang akan diprioritaskan terlebih dahulu. Setelah berbicara dengan anak-anak di kelompok saya, mereka sepakat untuk melaksanakan program-program yang ingin dilaksanakan.

Adapun program yang ingin dilaksanakan :

- kegiatan membaca buku

- kegiatan belajar sambil bermain

- kegiatan belajar dan membaca dengan media internet seperti youtube

- kegiatan sharing mengenai pembelajaran di sekolahnya

\section{Tahap Pelaksanaan Program (Intervensi)}

Pada tahap ini saya menjalankan program-program sesuai dengan perencanaan yang telah dibuat agar dapat berjalan dengan baik. Pelaksanaan program diawali dengan kegiatan membaca dan memahami tugas yang diberikan oleh ibu guru. Mereka sangat semangat untuk melihat dan memahami bacaan dan juga sangat kompak dalam mengerjakan soal-soal yang diberikan sehingga soalnya cepat terjawab. Kemudian program kedua dilaksankan pada pertemuan berikutnya adalah kegiatan belajar sambil bermain agar anak-anak lebih bersemangat, games yang diberikan tentunya tentang pengetahuan umum sehingga bisa menambah informasi buat mereka.Belajar berhitung dengan metode bergambar saya lakukan. Karena kebanyakan anak-anak lebih suka berhitung dengan melihat gambar-gambar dan memudahkan mereka dalam berhitung.

Saya tidak lupa untuk mengadakan kuis ditujukan untuk merefresh kembali dengan beberapa pertanyaan seputar pelajaran mereka di sekolah. Kuis yang diberikan dapat mereka jawab benar dan cepat. Setelah kuis, mereka sharing mengenai pembelajaran di sekolah mereka. Di pertemuan selanjutnya saya melakukan kegiatan belajar menggambar dengan tujuan untuk meningkatkan kreativitas mereka. Kemudian menerapkan metode membaca dan belajar dengan menggunakan youtube. Saya membantu untuk mengarahkan agar mereka dapat mengerti dengan pembahasan yang ada di youtube dengan pembahasan yang sederhana.

\section{Tahap Evaluasi dan Hasil Perubahan}

Di tahap ini saya melakukan evaluasi terhadap program-program yang telah dijalankan. Evaluasi pada program ini adalah lebih dibutuhkan pemantauan agar anak mau menjalankan programnya. Adapun hasil perubahan yang dialami oleh mereka adalah mereka lebih semangat dan ada kemauan membaca dan belajar bersama dengan anak yang lainnya sehingga bisa dengan cepat menjawab soal-soal yang diberikan oleh guru mereka. Mereka sangat merasakan manfaat dari program-program yang telah dilakukan selama PKL II di Panti Asuhan ini.

\section{Tahap Terminasi}

Tahap terminasi merupakan tahap dimana sudah selesainya hubungan secara formal dengan kelompok. Pada tahap terminasi ini saya menggabungkan dengan pemasangan poster mari membaca. Setelah pemasangan poster saya menyuruh anak-anak untuk membaca isi dari poster tersebut agar anak mengerti dan mengetahui informasi dari poster yang dibuat. Pemutusan hubungan dengan kelompok diawali dengan ucapan terima kasih karena telah menerima saya dan teman saya Selfian Harefa untuk melakukan PKL II di Panti Asuhan ini. Ada pemberian kesan dan pesan yang disampaikan oleh anak panti. Saya juga memberikan buku tulis agar anak-anak bisa rajin dan semangat belajar. Teknik analisis yang digunakan adalah teknik analisis deskriptif dimana penulis menggambarkan proses dari tahapan sosial casework. 


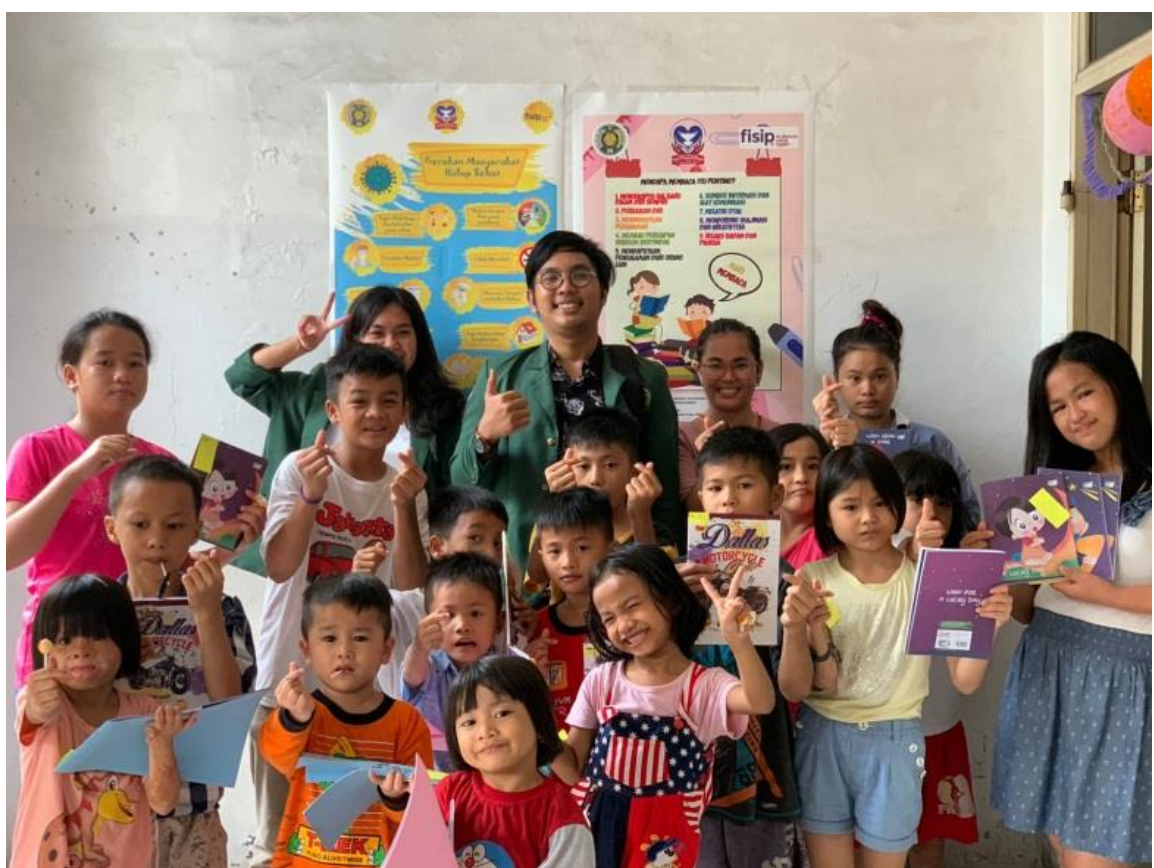

(Gambar 1. Pembagian buku tulis sebagai bentuk terminasi kepada anak panti.)

\section{HASIL DAN PEMBAHASAN}

Hasil dari mini project penulis adalah anak panti lebih semangat dan ada kemauan membaca dan belajar bersama dengan anak yang lainnya sehingga bisa dengan cepat menjawab soal-soal yang diberikan oleh guru mereka. Mereka sangat merasakan manfaat dari program-program yang telah dilakukan selama PKL II di Panti Asuhan ini. Di akhir pertemuan PKL II, kegiatan yang saya lakukan di apresiasi oleh Bapak Pengasuh yaitu Bapak Salim, beliau sangat berterimakasih atas kehadiran kami dan merasa sangat terbantu dalam mengisi kegiatan anak-anak selama masa pandemi

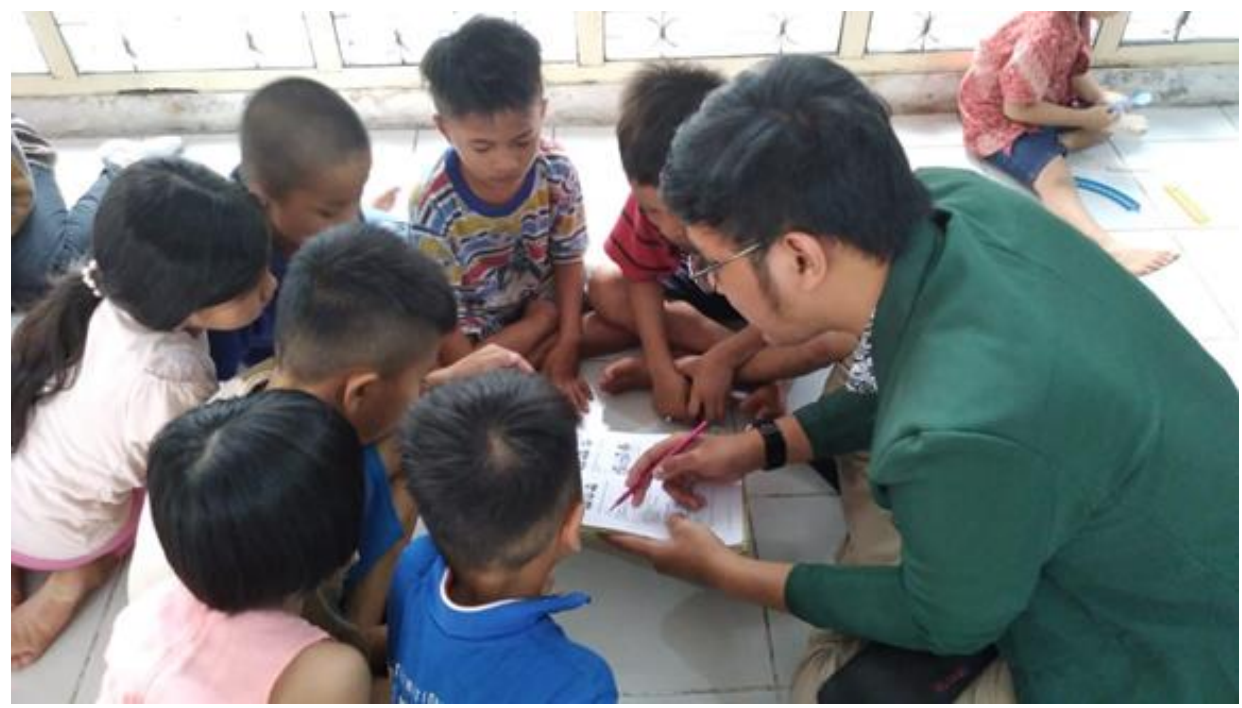

Gambar 2. Pelaksanaan Mini Project Untuk Meningkatkan Minat Baca Pada Anak Panti

Pemecahan (solusi) pada permasalahan yang dialami oleh anak panti adalah dengan adanya program yang berisikan kegiatan membaca yang menyenangkan maka anak dapat dengan nyaman dalam proses belajar baik di rumah maupun di sekolah. Timbulnya temuan baru seperti budaya membaca ini didasarkan pada teori social learning oleh Albert Bandura yang mengatakan bahwa jika orang dapat mempelajari informasi baru dan perilaku dengan melihat orang lain. Begitu juga dengan anak jika ia mendapatkan informasi baru dari yang saya ajarkan dalam kegiatan budaya membaca ini, anak juga melihat dan mengikuti untuk rajin dan menanamkan budaya membaca pada dirinya sendiri hal ini akan berdampak baik dalam mengikuti pembelajaran yang ia (anak) ikuti. 


\section{PENUTUP}

\section{Simpulan}

Dalam pelaksanaan mini project dalam praktikum kedua di Panti Asuhan Ora Et labora yang dilakukan oleh penulis, membawa pengaruh yang baik terhadap seluruh anak panti asuhan. Anak panti asuhan lebih rajin dan lebih minat untuk membaca buku buku yang dapat menambah wawasan baru bagi dirinya. Penulis juga berhasil dalam melaksanakan berbagai tahapan yang ada dengan membuat program untuk menanamkan budaya membaca pada anak. Hal ini diapresiasi oleh bapak panti karena membawa dampak yang baik pada anak khususnya dalam bidang pendidikan (education for the childern).

\section{Saran}

Saran dari penulis untuk anak-anak yang ada di panti adalah agar lebih semangat lagi dalam memperjuangkan masa depan dengan terus menanamkan budaya membaca. Saran juga kepada kakak abang dan bapak panti adalah untuk membantu dalam proses belajar anak karena anak-anak perlu pendampingan yang khusus sehingga dalam dirinya melekat budaya membaca.

\section{Ucapan Terima Kasih}

Penulis berterimakasih kepada Bapak Panti Asuhan Ora Et Labora Nusantara karena sudah menyambut baik penulis dari awal sampai akhir dari praktek kerja lapangan yang kedua ini.

\section{E. DAFTAR PUSTAKA}

Fahrudin, Adi (2012). Pengantar Kesejahteraan Sosial. Bandung: PT Refika Aditama.

Rukminto Adi, Isbandi (2015), Kesejahteraan Sosial. Jakarta : PT Raja Grafindo Persada.

Rukminto Adi, Isbandi (2013), Intervensi Komunitas Dan Pengembangan Masyarakat Sebagai Upaya Pemberdayaan Masyarakat. Jakarta : PT Raja Grafindo Persada. 